\title{
Von Willebrand disease type 2B
}

INSERM

\section{Source}

INSERM. (1999). Orphanet: an online rare disease and orphan drug data base. Von

Willebrand disease type 2B. ORPHA:166087

Type 2B von Willebrand disease (type 2B VWD) is a subtype of type 2 VWD (see this term) characterized by a bleeding disorder associated with an increase in the affinity of the Willebrand factor (von Willebrand factor; VWF) for platelets. This anomaly results in spontaneous binding of high molecular weight VWF multimers to platelets leading to rapid clearance of both the platelets (increasing the risk of thrombocytopenia) and the high molecular weight VWF multimers from the plasma. 